\title{
HEAVY RELIANCE ON THE INDIRECT FINANCING AS SOURCES OF FUNDS FOR BUSINESS FIRMS IN JAPAN: AS A COMPARISON FOR INDONESIAN FINANCIAL CRISIS
}

\author{
Yulius $^{1}$
}

\begin{abstract}
The purpose of this article is to study the implication of financial liberalization to the heavy reliance of firms to the indirect finance in Japanese experience. In order to analyze the goal of this article, we start to examine the causes of the main bank system in Japan before and the prewar period. Then, this article discusses the impacts of financial liberalization to the to the heavy reliance on the indirect-financing for business firms in the light with Japan's financial market, particularly the main bank system. Finally, this article also discusses the implication of loose relationship of big firms and major banks (main bank system) to the recent financial condition in starting from the early of 1990s until now. This article discovered that financial liberalization, which started at the latter half of 1970s, has shaken the foundation of the main bank system. The major firms started to less dependent on the major banks and they issued the securities in domestic and international market. As a consequence, the SMBS still depend on the banks as their source of indirect financing. However, the competitiveness in the SMBS market turned to erode the bank profits that induced them to enter the risk activities, such as real estate. In addition, the bubble burst economy also triggered the boom in real estate. Naturally, as a nature of risk asset, loan to the real estate became the potential of bad loans that also was exacerbated the bubble burst in economy. Then, the financial crisis has revealed in 1990s.
\end{abstract}

Keywords: finance, funds, Japan, business, firm, Indonesia

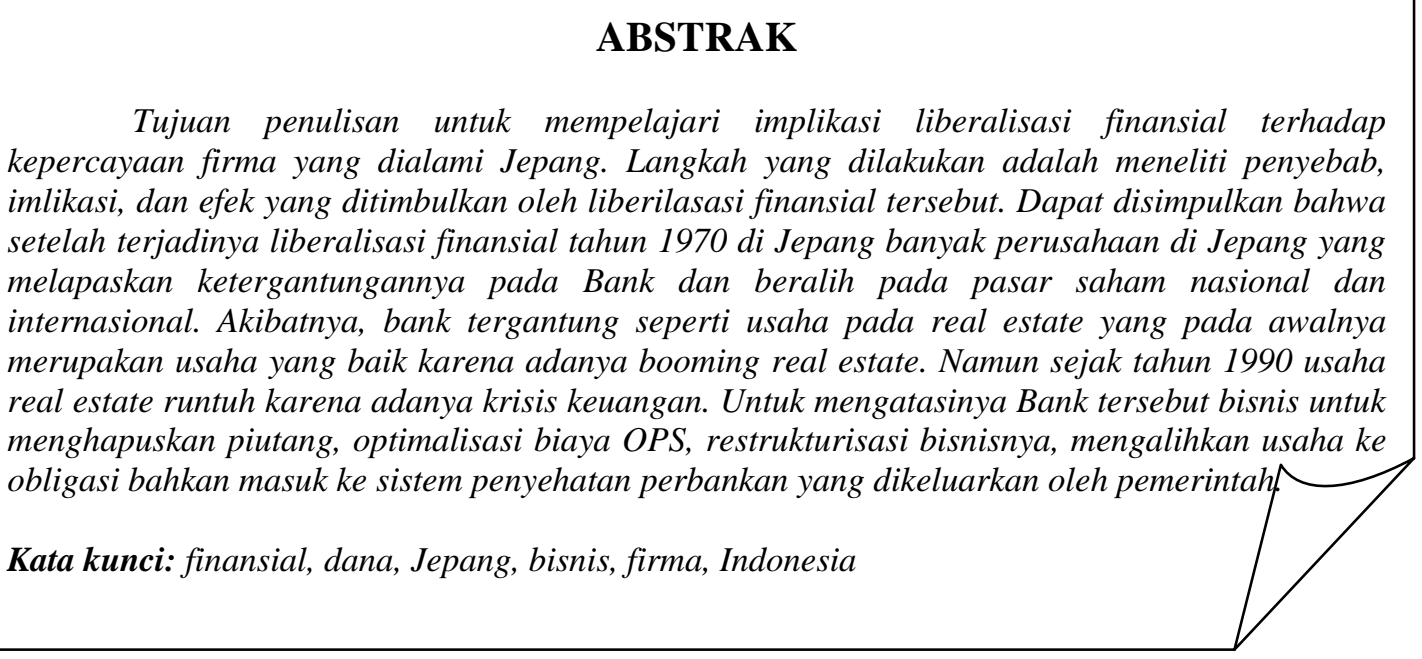

${ }^{1}$ Staf Pengajar Unika Atma Jaya, STIE Kalbe \& UBiNus, Jakarta 


\section{INTRODUCTION}

Japanese firms relied heavily on bank borrowings (indirect financing) during periods of rapid economic growth from the early 1950s to the early 1970s. The largest provider of bank loans (indirect finance) to a firm is usually identified as the firm's main bank. A main bank and its clients are typically linked in several ways. The main bank provides cash management and other financial services for the firm is often a major shareholder. The main bank sometimes sends its employees to serve as directors of the firms. The main bank is expected to be responsible for monitoring the firms and if the firms get into trouble, the main bank often intervene in the firm's management and tries to rescue it. This set of ties between banks and firms is called the main bank system (Detail explanation about the main bank system can be seen in Aoki and Patrick (1994)).

After the collapse of the Bretton Woods Agreement in 1971 (or 1973), the liberalization of both domestic and international financial started in the mid 1970s among industrial countries. The liberalization of financial market in Japan started in the latter half of 1970s like many other industrial countries. Therefore, it had an implication to the change of the Japanese financial market structures (The first oil shock in 1973 and foreign exchange law of 1980s also influenced the changing of Japan financial market. As a result lack of government deficit, the government issued a large scale- of deficit financing bonds. The foreign exchange law integrated the domestic Japanese financial market to international market (see Suzuki, 1987 and Feldman, RA, 1986)).

As a consequence, since the 1980's, we have seen a lot of changing in Japanese financial market. Firms' demand for investment funds and levels of internal funds have emerged in wide variation. Firms have developed and issued a sophisticated treasury functions. Firms have turned from bank borrowings to issuance of market securities (often through overseas market) in dramatic shift (Suzuki Y, 1987).

Therefore, the financial liberalization has changed the behavior of relationship among banks and firms. The main bank system has been shaken by financial liberalization. The big firms become less dependent on banks for their financing needs and move to securities market as their source of finances. On the other hands, small and medium business size (SMBS) firms still continued to depend on the banks as their source of finance since the Japanese securities markets had not been able to accommodate them with the stringent eligibility requirements for corporate bonds. Thus, SMBS became important market for banks, especially for small regional banks and cooperative credit banks. In accordance with the loose relationship with big firms, the City Banks and other major banks started to enter in SMBS market in the early 1980s. Therefore, the more banks in the limited market gave an impact to the high level of competition for banks to get the borrowers. In addition, liberalization on deposit interest rate started in 1985 also imposed the competition on the market (Horiuchi, 1996).

The competition imposed the erosion of banks' profit. Therefore, the commercial banks started to involve in excessive lending to risk taking activities, such as real estate, since in the middle 1980s in order to maintain their profit. In addition, the bubble economy, which started in 1987, also triggered the boom in real estate activities, which gave the incentive to the banks to give huge loans to the real estate activities. Then, excessive loans to the risky activities such as real estate influenced the potential bad loans that had created severe problems in Japan's banks in 1990s (Kitagawa, H and Y. Kurosawa, 1994). 
The purpose of this article is to study the implication of financial liberalization to the heavy reliance of firms to the indirect finance in Japanese experience. Therefore, the question will be addressed in this term article is what is the implication of financial liberalization to the main bank system The rest of this article will answer this question.

Section 2 will discuss an examination the causes of the main bank system in Japan before and the pre-war period. Section 3 will discuss the impacts of financial liberalization to the heavy reliance on the indirect-financing for business firms in the light with Japan's financial market, particularly the main bank system. Section 4 discusses the implication of loose relationship of big firms and major banks (main bank system) to the recent financial condition in 1990s. Section 5 contains a brief conclusion of this article.

\section{The Evolution of the Main Bank System}

In order to evaluate the heavy reliance on the indirect financing as source of funds for business firms, this article starts to discuss the evolution of the main bank system in Japan. Next, major changes in corporate financing during the fifteen years of war period led the creation of the prototype of the main bank system will be also discussed. Finally is to study how the banks acquired the monitoring capability during the heyday of main bank system.

\section{Pre war}

In the pre-war, the direct financing was the dominant of external financing for the firms. The dominance of financing through equities and bonds rather bank borrowing is more clearly observed for the Zaibatsu firm. Table 1 shows the proportion of major capital and liability items for a sample of Mitsui firm. The proportion of paid-in capital in total assets was higher for all the firms and borrowings from banks were not important for many firms. For example, the source of fund for Mitsui \& Co was based on of $68.1 \%$ paid in capital/total assets and was only $6.1 \%$ of borrowings from banks/total assets in 1920.

Table 1 Paid in Capital and Borrowings from Banks for Mitsui Zaibatsu in 1920

\begin{tabular}{llr}
\hline Company & $\begin{array}{l}\text { Paid-in capital/ } \\
\text { total asset } \\
(\%)\end{array}$ & $\begin{array}{l}\text { Borrowings } \\
\text { From banks/ } \\
\text { Total assets } \\
(\%)\end{array}$ \\
\hline Mitsui \& Co & 68.1 & 6.1 \\
Mitsui Mining & 66.7 & 0 \\
Hokkaido Tanko Kisen & 54.8 & 3.1 \\
Shibaura Seisakunso & 39 & 5.3 \\
Nihon Seiko-sho & 41.7 & 1.2 \\
Oji Article & 46.2 & 11.1
\end{tabular}


Table 1 Paid in Capital and Borrowings from Banks for Mitsui Zaibatsu in 1920 (continued)

\begin{tabular}{lrr} 
Dai Nihon Celluloid & 70 & 4.6 \\
Kanefuchi Boseki & 21 & 0 \\
Denki Kagaku Kogyo & 46.9 & 0 \\
Onoda Cement & 48.2 & 8.8 \\
\hline Source: Ito. T(1992) & &
\end{tabular}

Meanwhile, in case of Mitsubishi companies, as described by Ito (1992), the financing of Mitsubishi companies in 1930s were raised by selling shares to affiliates. In this case, funds from the parent companies in the form of paid-in capital were most important for them.

One of the reason why the banks borrowing were not an important sources of funds for many firms were a large number of small banks, and they frequently failed. Teranishi (1994) discussed that there were 1521 banks in 1904 but only 63 of them had equity larger than 1 million yen. In contrast, many of the remaining 1458 banks were very small: 390 banks had equity of less than 100.000 yen, another 528 had equity of between 100,000 yen and 300,000 yen. Moreover, 25 banks per year failed during the period 1902-1919, and 44 banks per year during the period 19201932 (Teranishi, 1994).

Instead, at in the prewar period, the shareholders had tight controls on Japanese companies and monitored managers closely. The fraction of equity owned by the largest shareholders was often high. The dividends of payout ratios were generally high. Managers typically were rewarded with bonus payments that were closely tied to profits. Shareholders were actively involved in management. Many large shareholders of non-Zaibatsu firms sat on the board and directly monitored the firms. One example is the monitoring mechanism at the Sumitomo zaibatsu, which was ruled by the Sumitomo House Accounting Rule. According this rule, each Sumitomo Company was required to submit its budget estimates and actual expenses to Sumitomo \& Co (Honsha) and obliged to explain any discrepancies between the two reports. Thus the Honsha was positioned to receive both the ex ante plans and ex post analyses of their members' activities. Monitoring of capital investment was especially strict. A Sumitomo firm had to submit a detailed report with included the estimated date and completion and expenditure for each year to Sumitomo \& Co. Moreover, when there was a change in any part of the projects, the firms had to consult the Honsha.

\section{Wartime}

The wartime was the origin of the main bank system. As discussed, a lot of banks were insolvent in the period of prewar. Therefore, in order to play an important role as indirect finance for the firms, the banks must be financially solvent. Moreover, it seems to be important to have relatively small number banks, because such a co-operative delegation mechanism would be difficult to implement with a large number of participants. This situation occurred in the period of wartime called main bank system. Therefore, the wartime was identified as the origin of the main bank system (Aoki, et all, 1994).

The concentration of the banking sector, which took place during the inter-war and during the war, produced a small number of large banks. Figure 2.1 shows the number of banks in Japan 
between 1901 and 1945. There were 1890 banks in Japan at the end of 1901, but only 61 by the end of 1945. There are two episodes of larger negative growth rate of banking industry, first was in the late 1920s and second was in 1940's.

The concentration during the 1920's had been influenced by several causes. First, financial crises in 1920, 1922, and 1927 forced smaller and weaker banks to go bankrupt or to be acquired by larger banks. Second, government policies (The Banking Law in January 1928) also encouraged mergers. That law stipulated a minimum amount of required capital, and pressured those banks which did not satisfy the requirement to merge before 1932. Third, the concentration during 1940s was mainly due to wartime financial controls, which aimed to allocate funds preferentially to war, related industries. Soon after Japan initiated war with China in July 1937, the Temporary Funds Adjustment Law was promulgated and a series of wartime financial controls was started. This law sought to control long-term funds, and preferentially allocate funds for warrelated industries. Finally, the Ministry of Finance (MOF) and the Bank of Japan (BOJ) often directly proposed mergers between banks in the name of efficiency. The MOF declared the goal of 'one prefecture-one bank' in May 1936, and aggressively advocated mergers between regional banks (Aoki, et all, 1994).

The concentration of the banking industry through the competition and aggressive government policies advocating mergers created a small number of larger banks, and laid some of the ground work for the main bank system. Table 2 shows sources of industrial funds for the period 1934 - 1944. This table shows clearly the increasing dependence on bank borrowing. The source of industrial funds from internal fund decreased from 54.8 \% in 1934 to $24.2 \%$ in 1944 . On the contrary, the bank loans as one of the sources of industrial funds increased from -11.4 in 1934 to $57 \%$ in 1944 .

Table 2 Source of Industrial Funds (\%)

\begin{tabular}{lllll}
\hline Year & Internal Funds & New Shares & New Bonds & Bank Loans \\
\hline & & & & \\
1934 & 54.8 & 55.4 & 2.8 & -11.4 \\
1935 & 51.6 & 32.9 & 1 & 14.9 \\
1936 & 47.4 & 33.5 & -2.3 & 18.3 \\
1937 & 33.3 & 35.5 & -0.1 & 31.9 \\
1938 & 30.5 & 34.6 & 5.4 & 29.9 \\
1939 & 27.1 & 24.5 & 7.9 & 38.4 \\
1940 & 30.4 & 26.7 & 5.5 & 38.3 \\
1941 & 33.6 & 29.1 & 10.1 & 28.1 \\
1942 & 31.3 & 25.7 & 8.9 & 32.8 \\
1943 & 30.3 & 22.6 & 7.8 & 35.8 \\
1944 & 24.2 & 9.1 & 8.3 & 57.8 \\
\hline
\end{tabular}

Source: Ito, $T$ (1992)

The major causes of this change in corporate financing was heavy industrialization accelerated by the war effort. During the inter-war period, capital-intensive heavy industries grew much more rapidly than light industries, and the war effort reinforced this tendency. Table 3 shows 
the share of output coming from the steel/metals and machinery industries increased from 27 percent in 1934 to 49 percent in 1942, while the fraction of production in the food and textiles industries declined from 42 percent in 1934 to 19 percent in 1942.

Table 3 Shares of Manufacturing Output 1924-42,

Private Companies with More than Five Employees, Percent

\begin{tabular}{lrrrrr}
\hline Industry & 1924 & 1929 & 1934 & 1939 & 1942 \\
\hline & & & & & \\
Steel \& Metals & 5.7 & 8.9 & 15.6 & 21.6 & 20.1 \\
Machinery & 6.7 & 8.8 & 11.5 & 20 & 28.7 \\
Chemicals & 11 & 14 & 16.1 & 18.4 & 17.2 \\
Textiles & 44.2 & 38.8 & 31.1 & 17.9 & 11.1 \\
Food & 16.3 & 14.6 & 11.1 & 9.3 & 7.6 \\
\hline
\end{tabular}

Source: Aoki and Patrick (1994)

The final important change to corporate finance during this period was the shift in corporate governance practice. Naturally, the firms started to depend on more external funds, especially bank loans. As a result, the relative power of shareholders declined somewhat. In addition, there were also regulatory changes that further limited the power of shareholders. The 1936 Corporate Profit Distribution and Fund Raising Order required firms with a dividend payout ratio of more than 10 percent to seek approval from the MOF. This rule severely restricted shareholders' rights to residual income. Therefore, this restriction on shareholder's property right must have reduced their incentive to influence and control management (Teranishi, 1994).

\section{Postwar}

As the war ended, Japan inherited a financial system with large banks and close bankfirm relations. Although this inheritance from the war economy was a major reason why the bank system emerged after the war, it was not the only one. The decline of shareholders' power during the war created a serious void in corporate governance: no one had the incentive or ability to monitor the managers of munitions companies. The absence of monitoring that characterized wartime financing had to be corrected, and the banks had to gain the power and the ability to monitor companies before the main bank system fully developed.

In this period, especially in the period of heyday of the main bank system (1951- 1975), the main bank's role in corporate financing and monitor was prominent and pervasive. Around 1951, marked the end of the post-war reconstruction period, particularly as it applied to establishing the architecture of the financial system, and the take-off the economy's high growth and escalating corporate investment demand. In the late 1949, the BOJ mediated the formation of loan consortia by city banks and involved itself in active ex ante monitoring of borrowing firms. In 1951, the Anti-Monopoly Act was revised and the ceiling on bank equity holding in non-financial firms was lifted from 5 percent to 10 percent. Also in 1951, the Japan Development Bank was founded as a government-owned development bank specializing in the provision of long-term investment financing, together with the Industrial Bank of Japan. 
In this period (1951-1975), a stable system existed in which banks and other financial institutions mobilized and allocated savings in a high-growth economy regulated by control over loan, deposit, and bond issue interest rates. Finance was mildly repressed. The demand for funds were in excess of supply because the market did not fully clear at the regulated rates and some credit rationing occurred, but real interest rates were positive. The new entry to the banking industry was prohibited, creation of new financial instruments restricted, and markets and financial institution activities segmented. Funds were, in practice, preferentially allocated among large business borrowers.

Table 4 presents the share of equity, bonds, and bank borrowings in the external financing firms with more than 1 billion in equity and stock exchanges. This table shows clearly that the percentage of bank borrowing as the source of corporate finance were high in the period 1957 to 1974 with the average around 70 percent. On the contrary, the trend of share equity and bonds decreased from the period 1957 - 1959 to the period of 1985 - 1988.

Table 4 Distribution of Sources of External Corporate Finance (\%)

\begin{tabular}{lrrr}
\hline Year & Equity & Bonds & \multicolumn{2}{c}{ Loans } \\
\hline & & & \\
$1957-1959$ & 20.5 & 11.1 & 68.3 \\
$1960-1964$ & 21.2 & 13.6 & 65.2 \\
$1965-1969$ & 8 & 12.1 & 79.9 \\
$1970-1974$ & 6.4 & 10.3 & 83.3 \\
$1975-1979$ & 19.6 & 25.3 & 55.1 \\
$1980-1984$ & 30 & 25.1 & 45 \\
1985 - 1988 & 38.6 & 51.4 & 10 \\
\hline Source: Aoki and Patrick(1984) & &
\end{tabular}

\section{DISCUSSION}

\section{The Implication of Financial Liberalization to the Main Bank System}

In order to know the impacts of heavy reliance on the indirect financing as sources of funds for business firms, the role of financial liberalization in the main banks system will be evaluated. After the financial liberalization, the foundation of the main bank system had been shaken. The banks moved their market to small and medium business size (SMBS) firms.

\section{Causes and Effects of Financial Liberalization}

During the growth era, Japanese financial transactions remained in small scale. The closed and controlled systems were maintained. Although some events, like liberalization of international trade and foreign exchange rate in 1960s, and being the OECD member, exposed the Japan's economy to international surroundings. Japan only allowed the foreign investors in the 
financial sector in limited access. So, highly regulation and largely isolation from international financial transactions were for more than three decades after the World War Two (Iwami T, 1995).

After the collapse of the Bretton Words Agreement in 1971 (or 1973), the liberalization of both domestic and international financial transactions started in the mid 1970s among industrial countries. This globalization was partly motivated by the need to control increasing inflation and partly by the need to enhance capital flow across countries (Ito, T, 1992). The liberalization of financial market in Japan started in the latter half of 1970s like many other industrial countries. Therefore, it had an implication to the change of the Japan financial market structures (Frankel, A.B and P.B. Morgan, 1992). In addition, the first oil shock in 1973 also influenced the changing of Japan financial market. As a result lack of government deficit, the government issued a largescale of deficit-financing bonds and tremendous expansions of the government occurred. Furthermore, the foreign exchange law of 1980 changed the Japan financial market with the increase of internationalization of real economy and high activity of cross-border fund flows. Therefore, this law integrated the domestic Japan financial market to international market (Feldman, RA 1986).

There are three points that should be as reflection to the effects of financial liberalization in the new era of the Japanese financial markets (Suzuki, Y 1987). First, the financial liberalization continued to weaken interest rate controls. The expansion of the large flotation of the government bonds expanded at extremely rapid pace that was spurred by Japanese bank regulations concerning the sales of government bonds in 1977. The expansion of the government bonds enhanced free interest rate in the open market as long-term instruments, short-term open market and relaxation or abolition interest controls.

Second, the Gensaki market (A Gensaki transaction is one in which there is a prior promise either to repurchase or to resell the same security as originally transacted after a fixed time and at a fixed price. Its market is free, open financial market in which any company may participate. The actual participants include securities companies, financial institutions, corporate entities, public financial institutions, and non-residents, such as foreign investors) which had existed on a small scale since 1950, also has expanded along with the growth of the government bond market in the secondary market since big firms became more sensitive to free interest rate. Part of the reaction of the Gensaki market, certificates of deposits (CDs) were established in May 1979 (The first CDs were issued in May 1979, and differ from regular deposit in that they are short-term deposits with free interest rates that may be sold to third parties). Thus, as a result of the foreign exchange law in 1980, yen deposit by non-resident and foreign currency deposits by resident also expanded by the increasing in the cross-border movement of funds. The development of Gensaki, CDs and cross-border movement contributed not only to the relaxation of interest control but also declining of the Japanese bank segmentations.

Third, the interest rate arbitrage increased rapidly not only in the domestic market but also in the foreign market as a result adaptation of a series of liberalization measures. The interest rate arbitrages expanded and diversified the open markets in both long and short-term assets. 


\section{Effects of the Indirect Financing for Business Firms as a Consequence Financial Liberalization}

As a consequences of financial liberalization, there were three implications to the Japanese banking system. First, firms started to less dependent on the banks as sources of indirect financing. Next, as a consequence of financial liberalization, the erosion of bank profits turned the bank to involve the risk activity such as real estate. Third, the erosion of bank profits also induced them involving on balance sheet activity.

\section{The Loose Relationship of Main Bank System}

As we have seen before, major banks maintained close relationship with the big firms in the period of high growth. However, this relationship declined after the financial liberalization. Big firms started to issue bonds in domestic market since the-mid 1980s and also to issue corporate bonds in the euro and other foreign markets. Thus, big firms became less dependent on banks for their financing needs and moved to securities market as their source of finances. On the other hands, SMBS firms still continued to depend on the banks as their source of finance because the Japanese securities markets had not been able to accommodate them with the stringent eligibility requirements for corporate bonds. Thus, SMBS became important market for banks, especially for small regional banks and cooperative credit banks. In accordance with the loose relationship with big firms, the City Banks and other major banks also started to enter in SMBS market in the early 1980s (see table 5)

The long-term relationship between major banks and firms seems to be have mitigated in the process of this structural change in corporate finance. According table 5, the major banks' loans to Keiretsu firms had been loosing their relative importance. The percentage of loans to Keiretsu firms to total amount of loans drastically decreased from 15.5\% in 1965 to only 3\% in 1990. This suggests that major banks had been forced to extend their credit outside of their intimate territories constructed by the "main bank relationship” during the high growth.

Table 5 Relative Importance of Major Bank Loans to Their Keiretsu Firms (Billion Yen)

\begin{tabular}{lrlr}
\hline Year & $\begin{array}{l}\text { Total Amount } \\
\text { of Loans }\end{array}$ & $\begin{array}{l}\text { Loans to } \\
\text { Keiretsu } \\
\text { Firms } \\
(\mathrm{B})\end{array}$ \\
& \multicolumn{3}{c}{$\begin{array}{l}\text { B/A } \\
(\%)\end{array}$} \\
\hline 1965 & 9,783 & 1,515 & 15.5 \\
1970 & 18,725 & 2,182 & 11.7 \\
1975 & 52,877 & 5,450 & 10.3 \\
1980 & 75,436 & 6,040 & 8 \\
1985 & 160,798 & 7,756 & 4.8 \\
1990 & 308,504 & 9,364 & 3 \\
\hline Source: Horiuchi $(1996)$ & &
\end{tabular}

Hea vy Relia nce on the Ind irect Fina ncing... (Yulius) 
Table 6 shows the increasing of bank loans to the SMBS market from 1991 to 1992, as the bank-intermediated financial needs of leading industrial companies declined. City, Trust and Long Term Banks all sought to increase loans to SMBS market.

Table 6 Loans to Small and Medium Firms as a \% of Outstanding Loans

\begin{tabular}{lrrrrrrrr}
\hline Type of bank & 1961 & 1966 & 1971 & 1976 & 1981 & 1986 & 1988 & 1992 \\
\hline & & & & & & & & \\
City & 26.6 & 23.7 & 25.8 & 29 & 37.7 & 44.4 & 51.2 & 57.9 \\
Long-term & 6.1 & 10.7 & 16 & 15 & 26.9 & 28.1 & 35.4 & 40.1 \\
Trust & 9.9 & 7.3 & 10.1 & 10.5 & 22 & 31.7 & 40.4 & 51.2 \\
Regional & 54.4 & 53.3 & 55.5 & 51.3 & 55 & 59.5 & 62.6 & 65.3 \\
\hline Source: Patrick and Park(1994) & & & & & &
\end{tabular}

\section{Increasing Loans to the Risky Activities}

As discussed above, there were a lot of banks in the SMBS market. Therefore, naturally, the more banks in the limited market gave an impact to the high level of competition that, in turn, gradually eroded the bank profitability. In addition, the liberalization of interest deposit became also the sources of the erosion of commercial bank profitability. These are the liberalization of interest rates on deposits started with the introduction of certificates of deposits in 1979, followed by liberalization of interest rates in large time deposits, small time deposits and demand deposits in 1985, and in 1990s (Takatsuki, A, 1998) (The succession of regulatory reforms that followed the authorization of CDs in 1979 caused the interest costs of banks to become increasingly sensitive to movements in the market interest rates. One change that was especially important in this process was the introduction of money market certificates (MMC) in 1985, with interest rates linked by formula to open market rates on designed instruments. As a result of their increased reliance on market rate funding during the period of sharply rising short term interest rates, the banks' pre tax profit declined sharply. In response the banks adjusted their methods of determining their prime rates for short and long term loans (in 1989 and 1991 respectively)).

As many banks entered in the market together with interest rate liberalization reduced the commercial bank profitability. Therefore, in order to maintain their profit, the commercial banks started to involve in excessive lending to risk taking activities, such as real estate, since in the middle 1980s. Consequently, bank competed vigorously for loans. This led to an enormous increase in real estate sectors in the 1980s, as can be seen in table 7. Credit analysis was relatively easy for these loans because it essentially amounted to forecasting future land and equity prices (The role of comprehensive safety net was also the source why the banks were very easy to give loans to the risky assets (see Horiuchi, 1996, 1998)). In addition, the bubble economy, which started in 1987, also triggered the boom in real estate activities, which gave the incentive to the banks to give huge loans to the real estate activities. 
Table 7 Share of Loans to Real Estate for Financial Industries

\begin{tabular}{lrr}
\hline Type of Banks & 1980 & 1991 \\
\hline & & \\
City & 8.1 & 18.9 \\
Regional & 6.9 & 15.9 \\
Trust & 17.5 & 40.5 \\
Long-term & 16.7 & 37.1 \\
\hline Source: Aoki and Patrick (1994) &
\end{tabular}

\section{Off Balance Sheet and Fee-Based Activities in the Early 1980's}

Off balance sheet activities started to increase in the early 1980s as banks looked for ways to offset decreases in profits from lending activities. The BIS regulation of the risk-asset ratio also encouraged banks with foreign business to increase such activities. Thus fees from foreign branches and subsidiaries started to climb in 1982, representing guarantees for bonds issued by local governments in the United States, currency and interest swap, merger and acquisitions advice, leveraged buyouts, option, and future.

Main banks, especially the top five city banks (top six since the creation of Sakura Bank) have aggressively increased their fee-based services domestically as well. These include the handling of cash balances and the settlement of promissory notes. Compared to the United States, fees traditionally have been very high in Japan.

\section{The Implication to the Recent Financial Market}

As mentioned above, the banks entered their business to the risk assets, such as real estate. This situation was triggered by inflation of asset price (bubble economy) in accordance of boom in real estate that could be the potential of bad loan, which revealed in 1900s.

\section{Inflation of Asset Price}

As discussed, the increasing of asset price also triggered the boom in real estate activities. In connection with the Plaza accord 1985, the Japanese government agreed to stipulate its economy in order to enhance domestic demand for U.S. products (Miller 1998). Therefore, the BOJ reduced the official discount rate starting from January 1986. The decrease of interest rate was followed with the increase of asset price, such as stock price and real estate.

The relation between property and stock market was very closed. The increasing of property prices stimulated the collateral value of individual assets that influenced to buy securities in the stock market. At the same time, the increase in securities demand could be used as collateral for loans to property market. In addition, big firms and banks also extended their portfolio to either securities or property market that was also a result of financial liberalization. Some firms went to these markets not to invest in plant or equipment rather to obtain cash for future needs. Other firms began to enter these markets in speculating rather that in concentrating their core business. 
At the same time, the Japanese banks also got a lot of profit from the bubble in stock market. The Japanese banks issued equities and convertible bonds as source of their finance. Thus, in stock price bubble, the Japanese banks could increase their hidden reserve. In addition, in order to follow the Bank for International Settlements (BIS) agreement, the Japan's banks could count $45 \%$ of unrealized appreciation in the Japanese bank portfolio of equity securities as Tier II capital for purposes of the risk-based capital rules. So, the Japanese banks could satisfy the BIS rules while the asset bubble occurred. Table 4.1 shows that the City banks increased their stock holdings during in the period of bubble economy (1987 - 1989). The increase of bank stock holdings turned the increased their hidden reserve that banks are not required to show unrealized capital gain on their balance sheets.

Table 8 City Bank Domestic Stockholdings

\begin{tabular}{|c|c|c|c|}
\hline Year & $\begin{array}{l}\text { At cost } \\
\text { (billion yen) }\end{array}$ & $\begin{array}{l}\text { As \% of } \\
\text { total assets }\end{array}$ & $\begin{array}{l}\text { Annual } \\
\text { increase (\%) }\end{array}$ \\
\hline 1955 & 35 & 1.1 & n.a \\
\hline 1960 & 151 & 1.9 & 34 \\
\hline 1965 & 389 & 2.1 & 20.8 \\
\hline 1970 & 899 & 2.4 & 18.2 \\
\hline 1975 & 1,992 & 2.5 & 17.5 \\
\hline 1980 & 3,676 & 3 & 13 \\
\hline 1983 & 5,207 & 3.3 & 12.3 \\
\hline 1986 & 7,228 & 3.8 & 11.6 \\
\hline 1987 & 8,761 & 3.5 & 21.2 \\
\hline 1988 & 11,412 & 4 & 30.3 \\
\hline 1989 & 15,062 & 4.6 & 32 \\
\hline 1990 & 18,596 & 5.3 & 23.5 \\
\hline 1991 & 20,207 & 5.8 & 8.7 \\
\hline
\end{tabular}

\section{Financial Difficulties in 1990’s}

At the end of May 1989, in order to go against the asset price bubble, the BOJ tightened monetary policy by raising official discount rate. The increase of interest rate also influenced the decrease of asset price. Therefore, the collapse of the asset prices influenced two hard implications to bank behavior. First, the borrowers (firms) got difficulties in relating to their loans. As a consequence the erosion of their earnings brought the banks suffer the bad loans. Some borrowers delayed repayment of principal and interest. These have been compounded by the falling collateral value of real estate due to the collapse of the bubble economy, therefore loan obligations to the financial institutions turns into bad loans (Economic Planning Agency, 1994) (The previous section has discussed that commercial banks could hide the bad loans by their profitability and hidden reserve before the bubble burst).

Second, the Japanese banks, which had extended large amounts of real estate financing or speculate in the share market boom, became the hardest hit by the collapse of bubble economy. 
The substantial decreasing of their hidden reserve was the main reason of the declining of the Japanese capital base due to the plunge of asset prices. The plunge of stock market wiped out the unrealized gain of the Japanese banks from securities portfolios as tools for satisfying with the BIS capital adequacy guidelines.

Those factors, difficulties of borrowers to repay their loans, the decrease of collateral value, the squeezing bank hidden reserves, damaged the banks' balance sheet that in turn brought the banks into the systemic financial crisis. Therefore, since the late 1980's Japan has suffered several difficulties in its banking sector. Some banks went bankrupt or at the brink at the bankruptcy. Others have been nationalized. Other banks have suffered the bad loan problems.

\section{CONCLUSION}

Generally, this article discovered that financial liberalization, which started at the latter half of 1970's, has shaken the foundation of the main bank system (It must be understood that financial liberalization itself is not a problem but the problem is how it si implemented). The major firms started to less dependent on the major banks and they issued the securities in domestic and international market. As a consequence, the SMBS still depend on the banks as their source of indirect financing. However, the competitiveness in the SMBS market turned to erode the bank profits that induced them to enter the risk activities, such as real estate. In addition, the bubble burst economy also triggered the boom in real estate. Naturally, as a nature of risk asset, loan to the real estate became the potential of bad loans that also was exacerbated the bubble burst in economy. Then, the financial crisis has revealed in 1990's.

The banks themselves and the government have tried to overcome Japan's financial crises. Some banks disposed and wrote-off their bad loans. Others cut their operating cost. Some other banks changed their business mix by curtailing their lending activities to construction companies and some banks went into the bond business. In addition, the government intervened by undertaking some efforts to help bank to overcome their problems, using monetary policy, implementing financial safety net, building the DIC and implementing capital adequacy regulation. Recently, the government has implemented the new regulatory system, management of financial failures, prompt corrective action system, and financial reform the so-called "big bank". However, although the banks and the government have done a lot of efforts, the sign of recovery in financial structure has not been yet in sight.

\section{REFERENCES}

Aoki, M, H. Patrick, and P. Sheard. 1994. "The Japanese Main Bank System: An Introductory Overview.” In M. Aoki and H. Patrick, eds., The Japanese Main Bank System: Its Relevance for Developing and Transforming Economies. New York: Oxford University Press.

Horiuchi, A. 1996. Financial Fragility and Recent Development in the Japanese Safety Net. Manuscript.

Hea vy Relia nce on the Ind irect Fina ncing... (Yulius) 
1998. “Case Studies for Crisis: Japan.” In Ross H. Mc Leod and Ross Garnaut, eds., East Asia in Crisis from Being a Miracle to Needing One. London: Routledge.

Feldman, R.A. 1986. Japanese Financial Market. Massachusetts: MIT Press.

Frankel, A.B. and P.B. Morgan. 1992. "Deregulation and Competition in Japanese Banking." Article presented at the Conference on Bank Structure and Competition sponsored by the Federal Reserve Bank of Chicago.

Ito, Takatoshi. 1992. The Japanese Economy. MIT Press.

Iwami, T. 1995. Japan in the International Financial System. London: Maxmillan Press

Miller, G.P. 1997. The Role of a Central Bank in a Bubble Economy http://www.goldeagle.com/editorials/

Suzuki, Y. 1986. Money, Finance, and Macroeconomic Performance in Japan. London: Yale University Press.

Suzuki, Y. 1987. The Japanese Financial System. Oxford: Clarendon Press.

Takatsuki, A. 1998. Lecture Note on Money and Banking in Japan. Fall Term in International University of Japan.

Teranishi, J. 1994. “Japan: Development and Structural Change of the Financial System.” In H.T. Patrick and Y.C. Park, eds., The Financial Development of Japan, Korea, and Taiwan: Growth, Repression, and Liberalization. New York: Oxford University Press.

Ueda, K. 1994. "Institutional and Regulatory Frameworks for the Main Bank System” in M. Aoki and H. Patrick, eds., The Japanese Main Bank System: Its Relevance for Developing and Transforming Economies, New York: Oxford University Press. 